\title{
Article \\ Agroforestry in the Czech Republic: What Hampers the Comeback of a Once Traditional Land Use System?
}

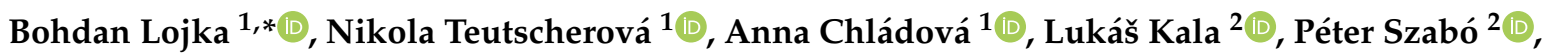 \\ Antonín Martiník ${ }^{3}{ }^{(D}$, Jan Weger ${ }^{4}$, Jakub Houška ${ }^{4}$ (D), Jakub Červenka ${ }^{4}$, Radim Kotrba ${ }^{1,5}{ }^{D}$, Jana Jobbiková ${ }^{4}$, \\ Helena Doležalová ${ }^{6}$, Martina Snášelová ${ }^{6}$, Jana Krčmářová ${ }^{7} \mathbb{D}$, Kamila Vávrová ${ }^{4}$ (D), Tomáš Králík ${ }^{8}$ (D), \\ Tomáš Zavadil ${ }^{6,9}$ (D) and Gerry Lawson ${ }^{10}$
}

check for updates

Citation: Lojka, B.; Teutscherová, N.; Chládová, A.; Kala, L.; Szabó, P.; Martiník, A.; Weger, J.; Houška, J.; Červenka, J.; Kotrba, R.; et al. Agroforestry in the Czech Republic: What Hampers the Comeback of a Once Traditional Land Use System? Agronomy 2022, 12, 69. https:// doi.org/10.3390/agronomy12010069 Academic Editor: Francisco Manzano Agugliaro

Received: 14 November 2021 Accepted: 27 December 2021 Published: 28 December 2021 Publisher's Note: MDPI stays neutral with regard to jurisdictional claims in published maps and institutional affiliations.

Copyright: (C) 2021 by the authors. Licensee MDPI, Basel, Switzerland. This article is an open access article distributed under the terms and conditions of the Creative Commons Attribution (CC BY) license (https:// creativecommons.org/licenses/by/ $4.0 /)$.
1 Faculty of Tropical AgriSciences, Czech University of Life Sciences Prague, Kamýcká 129, 16500 Praha-Suchdol, Czech Republic; teutscherova@ftz.czu.cz (N.T.); chladova@ftz.czu.cz (A.C.); kotrba@ftz.czu.cz (R.K.)

2 Institute of Botany of the Czech Academy of Sciences, Zámek 1, 25243 Praha, Czech Republic; lukas.kala@gmail.com (L.K.); peter.szabo@ibot.cas.cz (P.S.)

3 Department of Silviculture, Faculty of Forestry and Wood Technology, Mendel University in Brno, Zemědělská 3, 61300 Brno, Czech Republic; martinik@mendelu.cz

4 Silva Tarouca Research Institute for Landscape and Ornamental Gardening, Publ. Res. Inst., Květnové Náměstí 391, 25243 Praha, Czech Republic; weger@vukoz.cz (J.W.); houska@vukoz.cz (J.H.); cervenka@vukoz.cz (J.Č.); jobbikova@vukoz.cz (J.J.); vavrova@vukoz.cz (K.V.)

5 Department of Ethology, Institute of Animal Science, Praha Unříněves, Přátelství 815, 10400 Praha, Czech Republic

6 Association of Private Farming of the Czech Republic, Samcova 1, 11000 Praha 1, Czech Republic; helendol@seznam.cz (H.D.); martina.snaselova@asz.cz (M.S.); tomas.zavadil@asz.cz (T.Z.)

7 Institute of Ethnology, Czech Academy of Science, Na Florenci 1420, 11000 Praha 1, Czech Republic; jana.krcmarova@yahoo.com

8 Faculty of Electrical Engineering, Czech Technical University in Prague, Technická 2, 16627 Praha 6, Czech Republic; tomas.kralik@fel.cvut.cz

9 Department of Social Geography and Regional Development, Faculty of Science, Charles University, Albertov 6, 12843 Praha 2, Czech Republic

10 UK Centre for Ecology and Hydrology, Edinburgh EH26 0QB, UK; gerrylawson2@gmail.com

* Correspondence: lojka@ftz.czu.cz

Abstract: The interest in re-implementing agroforestry (AF) in European agriculture due to its environmental benefits has been growing exponentially. We reviewed the historical background and the current state (extent, farmers' perception, legislative support, and barriers) to evaluate the future perspectives of AF in Czechia by identifying the key factors hampering further extension. Our results confirmed that AF almost disappeared after the middle of the 19th century due to agricultural intensification and collectivization. Currently, AF is not defined in the Czech legislation and no modern AF has been encountered by this study. Areas falling into AF definition recently comprise only traditional AF (less than $1 \%$ of agricultural area remaining) represented only by silvopastoral $\mathrm{AF}$. The results of a farmers' survey indicated that despite relatively high interest in $\mathrm{AF}$, excessive bureaucratization, high costs of establishment and uncertain profitability are severe concerns among farmers. We therefore conclude that there is a lack of legal recognition and marginalization of AF as the key obstacles of low adoption rates. We suggest that systematic support beyond subsidies should include raising awareness, research, policy, legislation changes, training, and advisory service, as a cornerstone for progressive development of AF and thus conservation and creation of economically and environmentally sound landscapes throughout Czechia.

Keywords: agricultural policy; alley cropping; CAP; farmers perception; grazed orchards; silvoarable; silvopastoral; wood pastures 


\section{Introduction}

More than $70 \%$ of agricultural land is managed by large-scale enterprises in the Czech Republic, leading to a national average farm size of 121 ha, which is by far the largest average size in the EU. It greatly exceeds the EU average of 16.6 ha per farm $[1,2]$. These large blocks of generally homogeneous agricultural landscapes are characterized by low biodiversity and high vulnerability to soil erosion and degradation, which has severe implications for the sustainability of agriculture and food production. Intensive tillage and inadequate soil conservation practices have resulted in a substantial increase of the land surface threatened by water and wind erosion [3]. The current state of agriculture in the Czech Republic is representative of other post-communist Central and Eastern European countries, including Slovakia and former Eastern Germany [2], and is a result of the substitution of traditional agricultural landscapes formed by small family farms by intensively cultivated fields of (predominantly) monocultures. Family farms currently occupy less than $30 \%$ of agricultural land [3].

Although the total agricultural area was larger before the mid 20th century [4], it mainly consisted of a mosaic of small, diversified fields with trees and shrubs at the edges of fields, or within them [5]. However, the landscape changed considerably with the beginning of the communist regime in 1948 and the collectivization of agricultural areas [6] During the fifties, the majority of farms were incorporated into large cooperatives [7], which led to the unification of the field blocks and removal of woody vegetation (including thousands of trees alongside the roads) to facilitate the use of heavy machinery [6]. After the fall of the communist regime in 1989, the land was returned to its owners or their descendants, who, however, rarely cultivated the land themselves. Instead, the land was often leased [7] to large agricultural companies who continued the process of amalgamating fields and removing trees [8]. Although the scientific evidence is relatively scarce in comparison to other parts of Europe $[9,10]$, the current intensive and highly specialized agriculture based on excessive use of mineral fertilizers and pesticides leads to low (floral and faunal) diversity and (often irreversible) soil degradation [11].

In contrast, agroforestry (AF) is an example of "Sustainable Intensification", or how to get more outputs and greater diversity with fewer inputs. Hence, it addresses the negative environmental impacts of intensive agriculture, and its vulnerability to changing climate. Well-designed AF systems, which are adapted to local conditions, have a great capacity to provide economic benefits (in terms of higher productivity per se or reduced risks of production loss to biotic and/or abiotic stresses), while increasing the heterogeneity at the landscape level, which is beneficial for biodiversity conservation [12] and ecosystem functioning. Examples of traditional AF with high natural and cultural value successfully integrating food production and biodiversity conservation include the dehesas and montados of the Iberian Peninsula [13,14] or the wooded pastures, streuobst (grazed or intercropped orchard) and traditional hedges of Central Europe. The most frequent AF systems in Europe are two-layered wood pastures, where livestock production (mostly cattle or sheep) is combined with scattered large trees with an understory of native grasses [13]. These traditional forms successfully integrate food production, biodiversity conservation and high cultural value [14]. They are sometimes described as having "high nature and cultural value" (HNCV) [13].

Nevertheless, the re-adoption of agroforestry in Europe is currently challenging, despite the interest of both farmers and policy makers [15,16]. The valuation of trees on agricultural land by farmers has been addressed by only a few studies in Eastern Europe, most of them focusing on traditional wood pastures [17-19]. However, for the successful implementation of AF, both AF potentials as well as the current farmers' perception of ecosystem services and trade-offs of retaining and establishing trees on farmland must be understood [20] to design the guidelines to create strategies and policies for AF support. While the flexibility of $\mathrm{AF}$ in its spatial and temporal arrangement allows designs to be adjusted to different conditions [21,22], it also requires well-defined terminology and legislative options to be provided to farmers especially in highly bureaucratic European agriculture. 
In the European context, agroforestry is assumed to be the deliberate combination of trees and shrubs with agriculture, either as livestock or crop production. It can deliver ecosystem services without reducing agricultural productivity and has been extensively described and accepted in the tropics [21], where a wide range of different AF forms has been established [23]. One of the first definitions of AF [24] was "a collective name for a land-use systems and technologies where woody perennials are deliberately used on the same land-management unit as agricultural crops and/or animals, in some form of spatial and temporal arrangement". Since then, many other definitions have been suggested, particularly to describe land use systems in tropical countries. The European Commission gives a simple and practical definition in Article 23 of the Rural Development Regulation 1305/2013: "a land use system in which trees are grown in combination with agriculture on the same land" [25]. This definition includes combinations of trees and shrubs with agriculture, on either agricultural or forest land. On agricultural land, the trees can either be within parcels or on their edges.

While the overall definition is simple, there is a large number of AF practices in Europe that need to fit within a common typology across Member States. The European Agroforestry Federation (EURAF) has therefore suggested a typology of systems and practices (Table 1) [26]. In this paper, we focused on growing trees and shrubs on agricultural land. Opportunities for increased grazing on forest land will not be considered since it is currently prohibited by the Czech Forest Law.

Table 1. Agroforestry systems and practices proposed by EURAF (modification of Dupraz et al. [26] for use in the post 2023 CAP, particularly in the Integrated Administration and Control System and the Land Parcel Identification System (LPIS).

\begin{tabular}{|c|c|c|c|}
\hline \multirow[b]{2}{*}{ Tree Location } & \multirow[b]{2}{*}{ Agroforestry System } & \multicolumn{2}{|c|}{$\begin{array}{l}\text { Agroforestry Practice-According to EU Land Use Classification } \\
\text { (e.g., LPIS) }\end{array}$} \\
\hline & & Agricultural Land & Forest Land \\
\hline \multirow[t]{4}{*}{ Trees inside parcels } & Silvopastoral AF & Wood pasture & Forest grazing \\
\hline & Silvoarable AF & $\begin{array}{l}\text { Tree alley cropping } \\
\text { Coppice alley cropping } \\
\text { Multi-layer tree-gardens }\end{array}$ & $\begin{array}{l}\text { Forest farming (including } \\
\text { food forests) }\end{array}$ \\
\hline & Permanent crop AF & $\begin{array}{l}\text { Orchard intercropping } \\
\text { Orchard grazing }\end{array}$ & \\
\hline & Agrosilvopastoral AF & Alternating cropping and grazing & \\
\hline Trees between parcels & $\begin{array}{l}\text { Field boundary AF (Tree } \\
\text { Landscape Features) }\end{array}$ & $\begin{array}{c}\text { Wooded hedges } \\
\text { Windbreaks and shelterbelts } \\
\text { Trees in line } \\
\text { Riparian tree buffer zones }\end{array}$ & \\
\hline Trees in settlements & Urban AF & Homegardens, a & nents, etc. \\
\hline
\end{tabular}

Therefore, the main objective of this study was to unravel the factors hampering the re-adoption of AF in the Czech Republic. More specifically, we focused on: (i) the historical background of $\mathrm{AF}$, including its former use and the drivers of substitution by recently common industrial agriculture; (ii) estimation of the current extent of AF practices in the Czech Republic following the classification proposed by Dupraz et al. [26]; (iii) detection of the key barriers and motivation for AF adoption based on the farmers' perception (including their concerns and expectations); and (iv) identification of legal support and barriers for AF on EU level and in the Czech Republic, while also reviewing existing research, education and training. We hypothesized that the main challenge for re-adoption lies in the insufficient promotion of AF as a mainstream land-use through research, dissemination of information and policy changes [11] as well as in the insufficient adaptation and optimization of various 
AF practices to specific environmental, socio-economic and legislative conditions in the Czech Republic.

\section{Materials and Methods}

\subsection{Historical Review}

We qualitatively surveyed existing literature on the history of AF in the Czech Republic using the comprehensive overview in [27] as our main reference. The used archival sources included iconography, estate conscriptions, nation-wide cadastral surveys and theoretical writings on AF. The most comprehensive source we used was the Stable Cadastre (https: //ags.cuzk.cz/archiv/) (accessed on 11 February 2019), a nation-wide survey of land ownership and use for taxation in the mid-19th century. This included detailed information on AF outside forests (AF on arable land, meadows, and pastures) and inside forests (hay cutting, forest pasture and litter raking). Data from [28] focused on AF outside forests in 1689 settlements in Bohemia (Western part of the Czech Republic) were included. For AF inside forests in Moravia (Eastern part of the Czech Republic), we used the forest historical database originally created during the LONGWOOD project (www.longwood.cz) (accessed on 19 March 2019). Many types of historical sources (for example rent rolls, estate conscriptions and tax records) mainly from the 16th through the 19th centuries were scanned for references to various forest uses, including $\mathrm{AF}$, using a predefined query form. This form included the AF uses such as hay cutting, forest pasture, litter raking, pannage, wild fruit collecting, honey making and leaf fodder making, of which the first four were the most common. All information was localized in a GIS environment based on the existing 3564 settlements in the region. The database is the largest of its kind in Europe and contains ca. 33,000 entries on individual forests, including many thousand references to AF uses, which were filtered out for the study. The database is stored at the Institute of Botany of the Czech Academy of Sciences. A detailed description of the database as well as the processed archival sources and the employed procedures methods can be found in [29].

\subsection{Classification and the Extent of AF in the Czech Republic}

Following the current nomenclature of AF used in EU, we identified, defined and classified AF systems of historical, current or potentially future importance, to adjust the typology for the Czech Republic. To estimate the current extent of major AF systems, we used the methodology of [30], which consists of the localization of the areas fitting into the AF definition, with the use of datasets from EU surveys of Land Use and Cover Area Frame Survey (LUCAS). This is a geo-referenced database of 270,277 points that provide harmonized and comparable statistics on land use and land cover across the EU, 5515 of which are located within the Czech Republic. The points containing AF were identified using previously published methods [30,31]. Agroforestry was assumed to be present when the upper layer recorded scattered trees and the second identified the presence of crops or pastures. Agroforestry points were subsequently divided into three categories [26]: (i) silvoarable, where crops are integrated with trees on arable land; (ii) silvopastoral, where trees are combined with livestock production on pastures, and (iii) permanent crop AF, where fruit orchard are grazed or intercropped. All points that fitted the set criteria for AF in LUCAS, were then checked based on Czech LPIS (Land Parcel Identification System), and either orthophoto maps from the Czech Office for Surveying, Mapping and Cadastre, or personal visits. To estimate the extent of agroforestry in hectares based on points coded as AF and confirmed according to the criteria detailed above, we divided the number of points coded as AF by the total number of LUCAS points in Czech Republic and multiplied this by the surface of the country [30].

\subsection{Farmers' Perception of Agroforestry}

A methodology similar to that applied in previous studies [16] was used to understand the barriers and opportunities for the adoption and development of AF among Czech farmers. Qualitative data were obtained from focus group discussions (FGDs) carried out 
after workshops organized for farmers in 10 communities, in cooperation with Local Action Groups. The selected communities were located in two regions with the highest share of agricultural land, mostly arable land: Central Bohemia and South Moravia, in autumn 2018 and spring 2019. Each introduced the socio-economic and environmental benefits of AF, particularities of tree establishment and management, and to the current (limited) possibilities of growing trees on agricultural land in the Czech Republic. A semi-structured interview script was followed (see [32] for full details).

The FGDs were joined by self-selected participants $(n=113)$, mainly local farmers with some experience in tree-planting, who were asked to indicate their concerns and expectations of AF. The FGDs contributed to the formulation of the main positive and negative views of tree planting including agricultural production, legal and socio-economic impacts, which were then used for the preparation of a specific questionnaire used during the second stage. While the FG discussions targeted particularly small-scale farmers, and may not allow comparisons with other studies, they were useful for revealing the emerging patterns, and were a basis for further formulation of the questionnaire on expectations and concerns regarding agroforestry establishment.

After qualitative evaluation of the results from FGDs, we created an online farmers' survey questionnaire (available online in Open Science Framework) and it was distributed by email to 6492 Czech farmers/enterprises (recipients of agricultural subsidies as listed at the Ministry of Agriculture) in November 2019. By March 2020, we obtained 488 completed questionnaires ( $8 \%$ response rate). Most participants were private farmers ( $\mathrm{n}=350,72 \%)$ operating on an average of 50 hectares of predominantly arable land (Table 2). One hundred and thirty-nine participants $(28 \%)$ were large agricultural enterprises, including joint stock companies, managing several hundreds to thousands of hectares. Of all participants, $41 \%$ of farmers identified themselves as organic farmers (for details see online in Open Science Framework). Participants were asked to respond to each statement, using a 5-point Likert scale ranging from strong disagreement to strong agreement. The questions were designed to measure the farmer's perception of strengths and weaknesses of AF. The questionnaire also included open-ended questions allowing participants to share their opinions on pros and cons of AF. Data were processed in excel spreadsheet and analysed in SPSS software (IBM SPSS, Inc., Chicago, IL, USA). The Kruskal-Wallis test was used to determine whether there is a statistically difference between the expected frequencies and the observed frequencies in one or more categories of a contingency table. The farmers responses were also tested for their correlation with respondent farm characteristics and with the current tree distribution on their land using Spearman's correlations.

Table 2. Farm characteristics of the participants in farmers survey, together with the Likert scale median of the willingness to establish AF (medians followed by different letters are significantly different at $p<0.05)$.

\begin{tabular}{|c|c|c|c|c|c|c|}
\hline Farm Characteristics & Category & $\mathbf{n}$ & Share & Cumulative & \multicolumn{2}{|c|}{$\begin{array}{l}\text { Willingness to Establish } \\
\text { AF (Likerd Scale Median }\end{array}$} \\
\hline \multirow{3}{*}{ Legal status of farm } & Natural person/family farm & 349 & $72 \%$ & $72 \%$ & 4 & $\mathrm{a}$ \\
\hline & Business company & 114 & $23 \%$ & $95 \%$ & 4 & a \\
\hline & Cooperative & 25 & $5 \%$ & $100 \%$ & 3 & $\mathrm{~b}$ \\
\hline \multirow{3}{*}{ Management } & Organic & 198 & $41 \%$ & $41 \%$ & 5 & a \\
\hline & Conventional & 278 & $57 \%$ & $98 \%$ & 4 & $\mathrm{~b}$ \\
\hline & Not specified & 12 & $2 \%$ & $100 \%$ & 5 & a \\
\hline \multirow{6}{*}{ Farmland size } & up to 10 ha & 56 & $11 \%$ & $11 \%$ & 5 & $\mathrm{a}$ \\
\hline & $10-50$ ha & 102 & $21 \%$ & $32 \%$ & 4 & a \\
\hline & 50-100 ha & 106 & $22 \%$ & $54 \%$ & 4 & $\mathrm{~b}$ \\
\hline & $100-500$ ha & 128 & $26 \%$ & $80 \%$ & 4 & $\mathrm{~b}$ \\
\hline & $500-2000$ ha & 68 & $14 \%$ & $94 \%$ & 3 & c \\
\hline & over 2000 ha & 28 & $6 \%$ & $100 \%$ & 3 & c \\
\hline
\end{tabular}


Table 2. Cont.

\begin{tabular}{|c|c|c|c|c|c|c|}
\hline Farm Characteristics & \multirow{2}{*}{$\begin{array}{l}\text { Category } \\
\text { up to } 10 \%\end{array}$} & \multirow{2}{*}{$\begin{array}{l}\mathbf{n} \\
37\end{array}$} & \multirow{2}{*}{$\begin{array}{c}\text { Share } \\
8 \%\end{array}$} & \multirow{2}{*}{$\begin{array}{c}\text { Cumulative } \\
8 \%\end{array}$} & \multicolumn{2}{|c|}{$\begin{array}{l}\text { Willingness to Establish } \\
\text { AF (Likerd Scale Median) }\end{array}$} \\
\hline \multirow{6}{*}{$\begin{array}{c}\text { Share of privately owned } \\
\text { land }\end{array}$} & & & & & 3 & $\mathrm{a}$ \\
\hline & $10-30 \%$ & 122 & $25 \%$ & $33 \%$ & 4 & $a, b$ \\
\hline & $30-50 \%$ & 83 & $17 \%$ & $50 \%$ & 4 & $a, b$ \\
\hline & $50-70 \%$ & 88 & $18 \%$ & $68 \%$ & 4 & $a, b$ \\
\hline & 70-90\% & 51 & $11 \%$ & $79 \%$ & 4 & $b, c$ \\
\hline & over $90 \%$ & 104 & $21 \%$ & $100 \%$ & 4.5 & C \\
\hline \multirow{6}{*}{$\begin{array}{l}\text { Share of arable land in total } \\
\text { farmland }\end{array}$} & up to $10 \%$ & 137 & $28 \%$ & $28 \%$ & 4 & $a, b$ \\
\hline & $10-30 \%$ & 48 & $10 \%$ & $38 \%$ & 5 & $a, b$ \\
\hline & $30-50 \%$ & 43 & $9 \%$ & $47 \%$ & 4 & $b, c$ \\
\hline & $50-70 \%$ & 58 & $12 \%$ & $59 \%$ & 4 & $b, c$ \\
\hline & $70-90 \%$ & 93 & $19 \%$ & $78 \%$ & 4 & $c, d$ \\
\hline & over $90 \%$ & 109 & $22 \%$ & $100 \%$ & 3 & $\mathrm{~d}$ \\
\hline \multirow{4}{*}{ Number trees on farmland } & 0 & 99 & $21 \%$ & $21 \%$ & 4 & $\mathrm{C}$ \\
\hline & 1-10 & 190 & $40 \%$ & $61 \%$ & 4 & $\mathrm{~b}$ \\
\hline & 11-100 & 140 & $29 \%$ & $90 \%$ & 5 & $\mathrm{a}$ \\
\hline & over 100 & 50 & $10 \%$ & $100 \%$ & 4 & $\mathrm{~b}$ \\
\hline
\end{tabular}

Different letters indicate a statistically significant difference $(p<0.05)$ in the willingness of AF adoption expressed as a value on a Likert scale (1: strongly disagree to adopt; 5 : strongly agree to adopt) between farm categories within a farm characteristic using the Kruskal-Wallis test.

\subsection{Legal Aspects of AF in EU and Czech Republic}

Member States of the EU were permitted to support the establishment of agroforestry within their Rural Development Plans already in two Common Agriculture Policy (CAP) Periods (2007-2013 and 2014-2020). This support was available in two measures:

- CAP 2007-2013-Measure 222 “First establishment of agroforestry systems on agricultural land", which was implemented in 5 EU Member States: Belgium, France, Hungary, Italy and Portugal.

- CAP 2014-2020 Submeasure 8.2 "Support for establishment and maintenance of agroforestry systems", applied in 7 EU Member (and ex-Member) States: countries as before, Spain, and UK [33].

Since none of the mentioned measures has been implemented in the Czech Republic, the current programs of agricultural support (CAP, SGPFF- the Support Guarantee Agricultural and Forestry Fund, SEF-State Environmental Fund) were analysed to reveal at least partial current possibilities of AF support. We have also considered likely support under the new the Czech National CAP Strategic Plan, and requirements for AF training, research and development.

\section{Results}

\subsection{History of Agroforestry}

Considering the climate and terrain of the Czech Republic, it is reasonable to assume that both forest and open lands $[34,35]$ were used by the first farmers, with tree fodder (and thus AF in the modern sense) playing a crucial role in the local animal husbandry until its replacement with hay, which can be indirectly connected to the introduction of short scythes (tools for mowing grass, grain or other crops) in the Iron Age [36,37].

The first direct evidence of AF in the Czech Lands (including current Bohemia, Moravia and Silesia) can be found in written and pictorial sources. For instance, various medieval frescos and illuminations, particularly the 12th century fresco of Přemysl the Ploughman (the legendary ancestor of the Přmyslid dynasty) in Znojmo [38], depict arable fields with standing trees. Written sources provide information mainly on the agricultural use of forests, including grass cutting and hay preparation (on permanent meadows in forests or among the trees), litter raking (to be used as bedding for farm animals and later on as 
manure) and woodland pasture. Forest pastures were copiously documented and usually closely regulated systems. For example, the urbarium of the Hodonín city estate from the year 1691 [39] contains a detailed description of forest areas where grazing was permitted, with respective prices. Based on the Stable Cadastre of Moravia and Czech Silesia (the eastern part of the country, Figure 1) from the 1840s, there were 3564 settlements in this region, of which 697 (19.5\%) recorded hay cutting in forests, 2474 (69.4\%) litter raking and $1727(48.4 \%)$ pasturing in woodland, suggesting that AF was a very common practice in forests at the time. Intercropping of forest trees (polaření) was also traditionally practiced. It involved the planting of annual herbaceous crops between newly planted trees on forest soil during the first years after the establishment of tree plantations. It was promoted by foresters [40] and practiced in various forms until the 20th century, especially in lowland alluvial forests, e.g., in Southern Moravia. Farmers received access to a cheap and relatively fertile land to grow traditional crops (potatoes, fodder beet) while promoting the growth of young forest tree seedlings by weeding and other cultivation practices. Crop cultivation was usually practiced for the first three to four years of plantation, until the light competition prevented further intercropping.

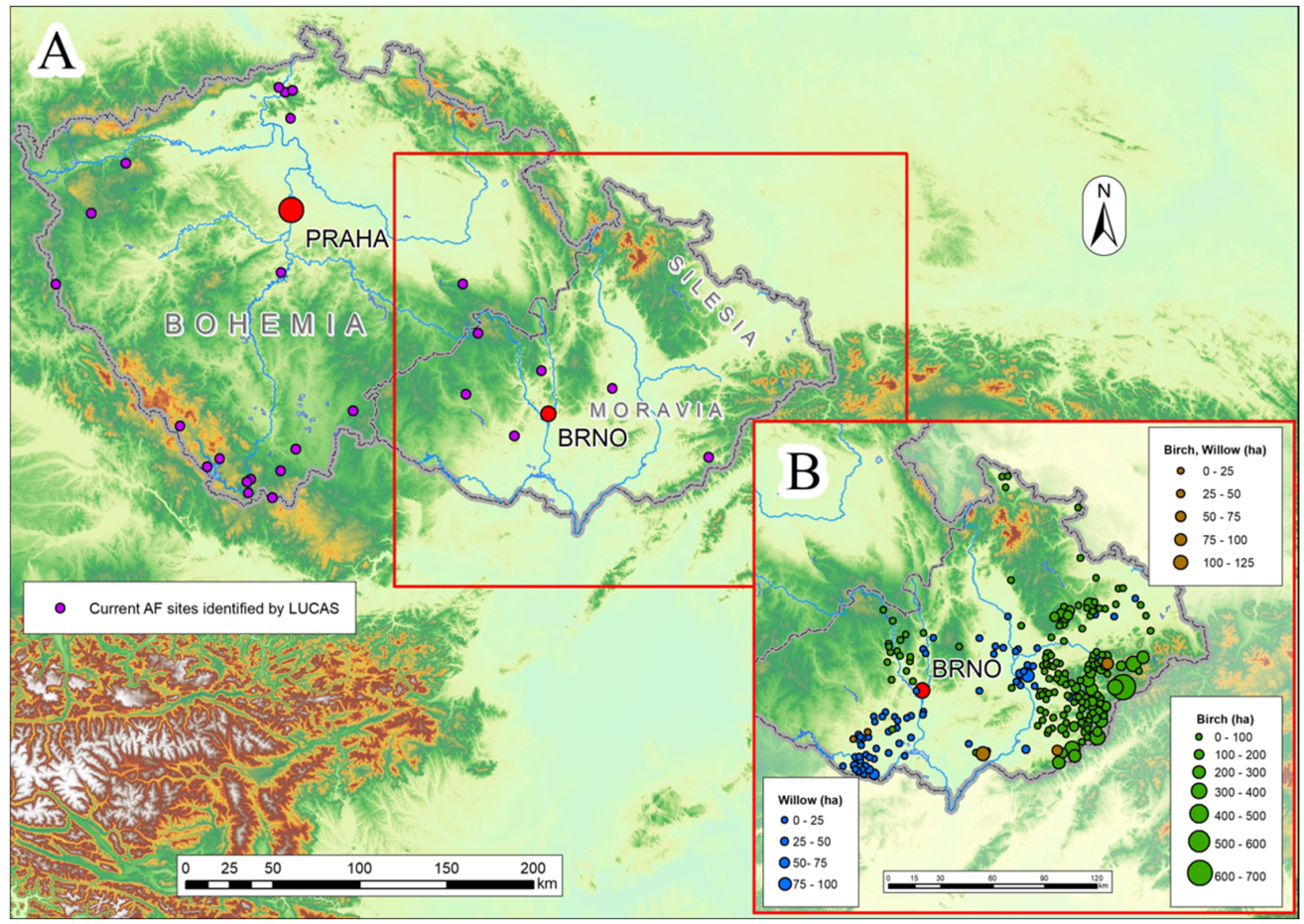

Figure 1. Agroforestry sites in the Czech Republic identified by LUCAS and confirmed by LPIS, orthophoto maps or personal visit (A), and pastures with trees in the 19th century in Moravia and Czech Silesia (B). Dominant tree species as well as the size of the pastures are indicated.

In addition, AF on agricultural land used to be a common practice until the midnineteenth century. Various forms of AF practices were all attuned to natural and cultural conditions: with more intensively managed fruit trees on pastures and meadows (fruit AF) in the proximity of highly developed lowlands with fertile soils; and trees for wood production (wood AF) in the more remote, mountainous regions. Comprehensive data on AF are available from the first half of the 19th century, when the Stable Cadastre was compiled (Bičík et al., 2015). This cadastre included several AF land use categories, of which the most common were arable land with fruit trees (Acker mit Obstbäumen in the original German), meadows with fruit trees (Wiesen mit Obstbäumen), meadows with wood use (Wiesen mit Holznutzen), pastures with fruit trees (Hutweiden mit Obstbäumen) and pastures with wood use (Hutweiden mit Holznutzen). Even though the Stable Cadaster is 
by any standard an extremely detailed historical source on land use types, other possible AF uses-for example trees in home gardens-were not recorded in any comprehensive manner. A detailed analysis of a single village (Velký Uhřínov, in NE Bohemia) was carried out [27], and it was detected that $3.5 \%$ of all agricultural land could be classified as AF. It was also observed that $3.6 \%$ of agricultural land in $\mathrm{W}$ Bohemia was used for AF in the mid19th century [28]. As for pastures with trees, the Stable Cadastre recorded two basic types: either short rotation (5-6 years) willow pollards or longer rotation (ca. 25 years) birches in lowlands and at higher elevations (Figure 1B). In the latter category, trees on average covered approximately $40 \%$ of the pastures and probably resulted from spontaneous succession in spite of the relatively high numbers of grazing domestic animals [41].

However, by the end of 19th century, no written signs of AF in the official literature could be detected [27], as the agricultural use of the forests was abandoned due to its alleged harmful effects [42]. AF in general was abandoned due to political, socio-economic and demographic changes [28]. In particular, the pressure of agricultural intensification led to: (i) the substitution of orchard agroforestry with large-scale intensive agricultural production on fertile soil, and (ii) the abandonment of less fertile areas of silvopastoral systems (particularly at higher elevations) and their change to productive forest, due to their generally low production potential when compared to lowland agriculture or intensive cattle husbandry. To facilitate the mechanization and intensification of agriculture, especially after World War II, and during the era of communist collectivization (1945-1990), the remaining trees (solitary trees, alleys, or live hedges) were gradually removed from agricultural land, leading to the nearly complete disappearance of AF from Czech landscapes. Most of those remaining trees, which survived on agricultural land, are currently registered as Landscape Features, or occur on non-productive so called 'other' agricultural land in Czech LPIS.

\subsection{Classification and Current Extent of Agroforestry}

According to the current classification of AF in Europe [26], five major categories with eight subcategories of AF practices were identified to be of importance in the Czech Republic. The historical and current AF practices as well as those that are likely to be recognized by the Czech legislatives in the near future are listed in the Table 1. According to data from LUCAS database, the total area of AF in the Czech Republic is 35,750 ha (corresponding to less than $1 \%$ of utilized agricultural area), which is solely represented by silvopastoral AF, particularly by established forest trees on pastures, here classified as wood pastures ( $30,030 \mathrm{ha}, 84 \%$ of total AF area) and grazing under fruit trees, classified as orchard grazing (5720 ha, 16\%) (Table 3). The majority of the areas classified as AF according to LUCAS were located in the areas with challenging environmental conditions, usually highlands covered with permanent grasslands used for extensive livestock husbandry (Figure 1). Using LUCAS, we were not able to detect any other AF practices. 
Table 3. Classification, description, support and extent of agroforestry (AF) in the Czech Republic.

\begin{tabular}{|c|c|c|c|c|}
\hline Agroforestry System (AFS) & Agroforestry Practice & Description & Extension & Example \\
\hline \multirow{4}{*}{$\begin{array}{l}\text { Silvoarable } \\
\text { (trees inside parcels) }\end{array}$} & \multirow[t]{2}{*}{ Tree alley cropping } & $\begin{array}{l}\text { Forest or fruit trees in lines within fields; final } \\
\text { number of target trees is } 80-100 \text { per ha; } \\
\text { distance of rows } 10-40 \mathrm{~m} \text {, spacing of trees in } \\
\text { lines } 3-10 \mathrm{~m} \text {, area covered by trees } 5-25 \%\end{array}$ & Only experimental & \\
\hline & & $\begin{array}{l}\text { Suitable for subsidy under the National Strategic } \\
\text { Plan 2023-27 (NSP). } \\
\text { LPIS category-arable land }\end{array}$ & Potential novel $A F$ & \\
\hline & \multirow[t]{2}{*}{$\begin{array}{l}\text { Coppice alley cropping-Short } \\
\text { rotation coppice (SRC) tree belts }\end{array}$} & $\begin{array}{l}\text { Strip planting of trees suitable for coppicing } \\
\text { (production of wood biomass } 2-4 \text { belts per ha } \\
\text { each consisting of } 2-4 \text { lines }(0.5 \times 2 \mathrm{~m} \text { ), about } \\
1000-2000 \text { plants } / \text { ha. }\end{array}$ & Only experimental & \\
\hline & & $\begin{array}{l}\text { Not suitable for subsidy under NSP, nor under any } \\
\text { existing programme. } \\
\text { LPIS category—arable land }\end{array}$ & Potential novel AF & \\
\hline \multirow{4}{*}{$\begin{array}{l}\text { Silvopastoral } \\
\text { (trees inside parcels) }\end{array}$} & \multirow[t]{2}{*}{ Wood pastures } & $\begin{array}{l}\text { Forest species on the pastures, improving } \\
\text { animal welfare. The tree density } 80 \text { to } 100 \\
\text { fully-grown trees per ha, scattered or regularly } \\
\text { planted. }\end{array}$ & 30,030 ha $(84 \%)$ & \\
\hline & & $\begin{array}{l}\text { Suitable for subsidy under NSP. } \\
\text { LPIS category - permanent grassland }\end{array}$ & Current practice & \\
\hline & \multirow[t]{2}{*}{ Silvopasture with SRC trees } & $\begin{array}{l}\text { Combination of SRC plantations with domestic } \\
\text { animals (poultry, pigs). Single- or double-rows } \\
\text { of trees about } 2-4 \mathrm{~m} \text { apart, the spacing within } \\
\text { row } 0.5 \text { to } 2.0 \mathrm{~m},(1500-10,000 \text { trees per ha). }\end{array}$ & Only experimental & \\
\hline & & $\begin{array}{l}\text { Not suitable for subsidy under NSP, nor under any } \\
\text { existing programme. } \\
\text { LPIS category-short-rotation coppice }\end{array}$ & Potential novel AF & \\
\hline
\end{tabular}


Table 3. Cont.

\begin{tabular}{|c|c|c|c|c|}
\hline Agroforestry System (AFS) & Agroforestry Practice & Description & Extension & Example \\
\hline \multirow{2}{*}{$\begin{array}{l}\text { Permanent crop } \\
\text { agroforestry-silvoarable } \\
\text { (trees inside parcels) }\end{array}$} & \multirow{2}{*}{ Orchard intercropping } & $\begin{array}{l}\text { Traditional AFS, where high stem fruit varieties } \\
\text { are intercropped with traditional arable crops. }\end{array}$ & $\begin{array}{l}\text { No data, remnants of once } \\
\text { traditional systems }\end{array}$ & \\
\hline & & $\begin{array}{l}\text { Not suitable for subsidy under NSP, nor under any } \\
\text { existing programme. } \\
\text { LPIS category-orchard }\end{array}$ & Current practice & \\
\hline \multirow{2}{*}{$\begin{array}{l}\text { Permanent crop } \\
\text { agroforestry-silvopastoral } \\
\text { (trees inside parcels) }\end{array}$} & \multirow{2}{*}{ Orchard grazing } & $\begin{array}{l}\text { Traditional AFS, where high stem fruit varieties } \\
\text { are grazed. The tree density usually } \\
\text { 50-200 trees per ha regularly planted. }\end{array}$ & 5720 ha $(16 \%)$ & \\
\hline & & $\begin{array}{l}\text { Not suitable for subsidy under NSP, but suitable for } \\
\text { support under already existing environmental } \\
\text { programmes. } \\
\text { LPIS category—orchard }\end{array}$ & Current practice & \\
\hline \multirow{2}{*}{$\begin{array}{l}\text { Field boundary agroforestry } \\
\text { (trees between parcels) }\end{array}$} & \multirow{2}{*}{$\begin{array}{l}\text { Windbreaks, shelterbelts, wooded } \\
\text { hedges, riparian tree strips }\end{array}$} & $\begin{array}{l}\text { Tree lines at the edges of land or around field } \\
\text { blocks for wind and water erosion reduction, } \\
\text { provision of clean water, and/or separation of } \\
\text { field blocks. May be combined with productive } \\
\text { function of trees. }\end{array}$ & No data & \\
\hline & & $\begin{array}{l}\text { Not suitable for subsidy under NSP, but suitable for } \\
\text { support under already existing environmental } \\
\text { programmes. } \\
\text { LPIS category_landscape feature }\end{array}$ & Current practice & \\
\hline \multirow{2}{*}{$\begin{array}{l}\text { Urban agroforestry } \\
\text { (Trees in settlements) }\end{array}$} & \multirow{2}{*}{ Homegardens, allotments, etc. } & $\begin{array}{l}\text { Combination of fruit trees with vegetable or } \\
\text { berries production and/or poultry/small } \\
\text { ruminant husbandry on the ground level. }\end{array}$ & No data & \\
\hline & & $\begin{array}{l}\text { Not suitable for subsidy under NSP, nor under any } \\
\text { existing programme. } \\
\text { LPIS category—other culture }\end{array}$ & Current practice & \\
\hline
\end{tabular}




\subsection{The Farmers' Perceptions of Agroforestry}

In the FG discussions, we observed that the participants were rather production oriented, locked in a "feeding the country" paradigm. Common scepticism and negative prejudices have been observed regarding the cultivation of trees on agricultural land, especially on arable land. Farmers often assumed that high labour-intensity and skills were required for such practices, while expressing their concerns regarding the competition between the trees and the crops for resources. Participants called for tailor-made solutions from public authorities, such as guides, accompanied with subsidies for AF. They did not consider themselves sufficiently skilled to design and maintain AF on their own. The absence of practical examples or demonstrations of AF farms in the Czech Republic, together with the inexistence of support in the form of training materials and advisory service, deepens farmers' concerns based on the established stereotypes: (i) geographicalAF is not suitable for temperate climate; (ii) ecological—woody vegetation has always been considered as an 'enemy' of modern farming due to the tree-crop competition and obstacles for mechanization; (iii) social—farmers view themselves as producers of crops or animals, and growing trees will lead to the marginalization of farming; (iv) economicaltrees cultivated on fields do not pay-off economically; and (v) political-it is a tool to get agriculture under the control of officials. The detailed results of the FG discussions are presented in [32].

Despite relative scepticism expressed by farmers during FG discussions over the inclusion of trees within agricultural systems, the results of the quantitative farmers' survey based on the questionnaire revealed that only $21 \%$ of farmers had no trees on their farmland, while $64 \%$ reported up to 50 trees on their farmland. Most of the farmers $(80 \%)$ with established trees are convinced of the aesthetical function of woody vegetation in the landscape (Figure 2). Over 59\% of farmers agreed that trees play an important role in soil protection, particularly in erosion control. Nevertheless, more than two thirds of farmers claimed not to have any direct economic benefit from the presence of trees, and nearly the same number did not believe that trees increase efficiency of their main agricultural activity. Only a minority of the farmers (less than $20 \%$ ) claimed that woody vegetation on their farmland possess any legal protection, while they generally do not receive any subsides to maintain it.

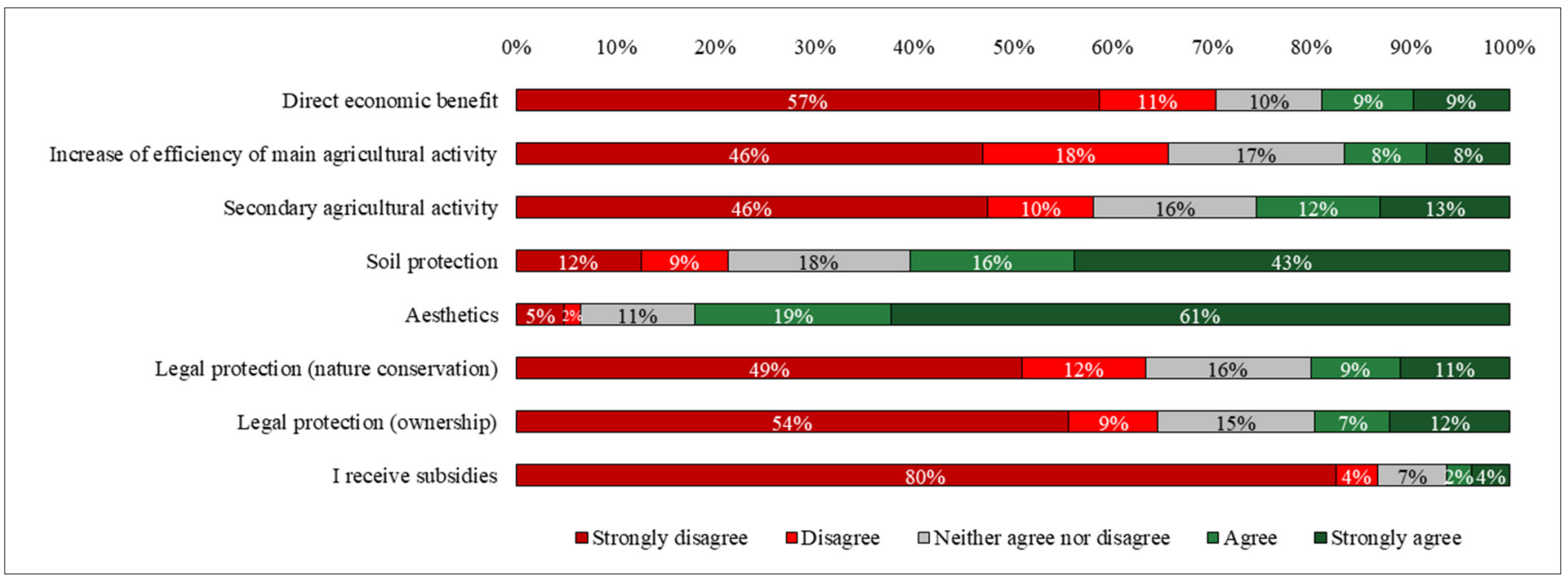

Figure 2. Reasons why farmers retain the trees on their agricultural land. Numbers indicate the percentage of farmers from the total number of farmers $(n=448)$.

A low number of participants were completely against the cultivation of trees on their land (only $10 \%$ were strongly against the idea of starting up $\mathrm{AF}, 11 \%$ were somewhat against). Nearly two thirds (64\%) of participating farmers were willing to establish AF on 
their own land while a quarter $(24 \%)$ would establish it even on the leased land. However, the relatively higher representation of organic farmers in our survey $(41 \%$, while current share is around $10 \%$ of all farmers in Czechia) likely limits the generalization of those results. Of those farmers willing to establish $\mathrm{AF}$, silvopastoral $\mathrm{AF}$ was preferred by $59 \%$ of farmers and $34 \%$ of farmers would opt for silvoarable AF. We found a statistically significant $(p \leq 0.05)$ influence of the farm characteristics on the willingness of the farmers to establish $\mathrm{AF}$ (Table 2). A higher tendency to establish AF was expressed by organic and relatively small (up to $50 \mathrm{ha}$ ) farmers who own most of their farmland, have a lower share of arable land in total farmland (mixed farming) and already maintain a number of trees on their land. The median of the preferable size of the farmland dedicated to AF establishment was 8 ha, while 37, 18 and $16 \%$ of farmers would establish AF on up to 10, 20 and 50 ha, respectively. The majority (74\%) of small farmers (up to 10 ha of farmland extension) are keen to establish AF. The willingness to establish AF was negatively correlated $(p<0.001)$ with the total size of the farmland (Figure 3a) and share of arable land in the total farmland ( $\mathrm{rs}=-0.259$,) (Figure 3c), and positively correlated with the share of privately owned land to the total farmland $(\mathrm{rs}=0.161$ ) (Figure $3 \mathrm{~b}$ ) and number of trees, which are already present on their farmland ( $r s=0.265)$ (Figure 3d).

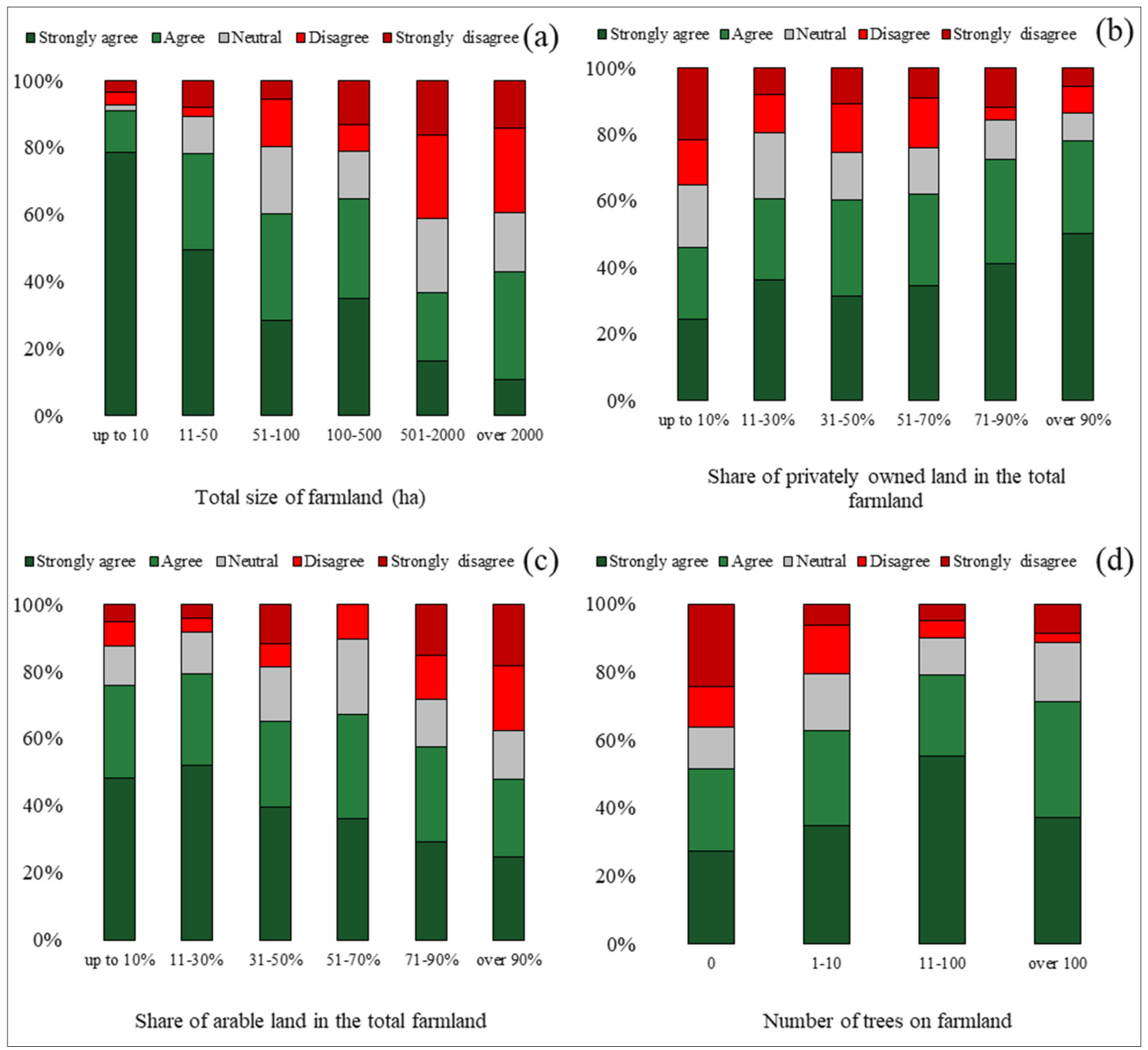

Figure 3. The willingness of farmers to establish AF based on (a) total size of farmland, (b) share of privately owned land in the total farmland, (c) share of arable land in the total farmland, (d) number of trees on farmland. 
When asked about their expectations of the benefits of AF on their farmland, most farmers agreed on the beneficial function of trees in microclimate improvement $(76 \%)$, erosion control (71\%), overall biodiversity conservation, and pest control (50\%) (Figure $4 \mathrm{a})$. These functions are linked with an expected improvement of the farming image $(60 \%)$. However, only $26 \%$ of farmers believe that growing trees can improve soil fertility and thus increase productivity of adjacent crops or pastures. Concerning the productive role of trees, only $32 \%$ of farmers expected the adoption of $\mathrm{AF}$ to be economically beneficial due to the diversification of their production. Any kind of financial subsidy for establishment of AF would be an additional motivation for roughly half of interviewed farmers.

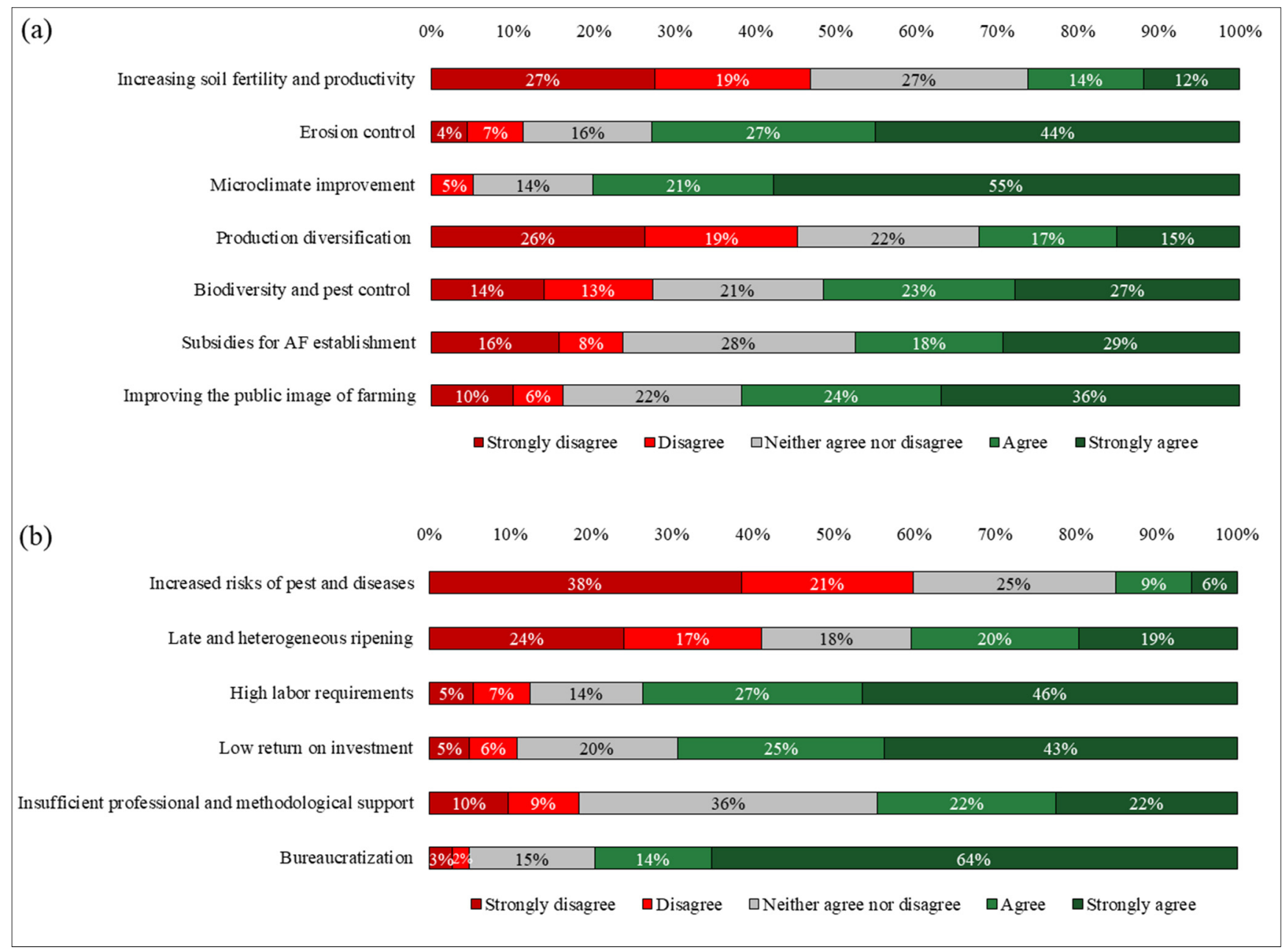

Figure 4. Farmers' (a) expectations from and (b) concerns of the establishment of AF.

Looking at the major concerns connected with AF (Figure 4b), the majority of participants stated that AF establishment and management would involve higher labour requirements $(73 \%)$, while giving a low return on the investment $(68 \%)$. The biggest concern, however, lies in the bureaucratization of the process of AF establishment under the current legislation (79\%). Insufficient professional and methodological support for AF was identified by $44 \%$ of farmers. To overcome this, farmers would appreciate practical excursions $(59 \%)$, seminars $(58 \%)$, and printed training handbooks $(49 \%)$ for guidance during AF establishment and the initial maintenance phase. 


\subsection{Current Legislation of Agroforestry in EU and Czech Republic}

\subsubsection{European Legislation}

Agroforestry was mentioned four times in the first EU 1998 Forestry Strategy (COM 1998/649), but its uptake was not tracked in the evaluation of this Strategy (Commission staff working document-Annex to the: Communication on the implementation of the EU Forestry Strategy (No. COM (2005) 84 final SEC/2005/0333)). Similarly, the 2006 EU Forest Action Plan (Communication from the Commission to the Council and the European Parliament of 15 June 2006 on an EU Forest Action Plan, 2006) invited Member States to "promote agroforestry systems" in their rural development programs, but there was no mention of AF in the 145-page-long evaluation of progress made under this Action Plan [43]. In 2013, the second Forest Strategy (European Commission, 2013, Forest Strategy: for forests and the forest-based sector) stressed agroforestry in the context of national Rural Development Programs, but again failed to include it in the specific targets of the MultiAnnual Implementation Plan (European Commission, 2015, Multi-annual Implementation Plan of the new EU Forest Strategy).

The First Pillar of the CAP covers direct payments to farmers in Member States. Regulation (EU) No 1307/2013 (Regulation establishing rules for direct payments to farmers under support schemes within the framework of the common agricultural policy (No. Regulation 1307/2013), 2013), Article 43 (and Delegated Regulation 639/2014), which describes rules for "payments for agricultural practices beneficial for the climate and the environment": generally known as "greening", to which EU countries have to allocate 30\% of their direct payments. There are three greening rules: crop diversification, maintenance of permanent grassland and Ecological Focus Areas (EFAs). The EFAs comprise land that is "beneficial for biodiversity", and which all (non-organic) farmers with more than 15 ha of arable land must declare on their annual agricultural returns, covering at least 5\% of their farm. EFAs are relevant to agroforestry since "hectares of agroforestry" and most "Landscape Features" involve trees.

The Second Pillar of the CAP supports Rural Development Programmes in Member States. Unlike the first pillar, rural development payments are co-funded by contributions from Member States. In 2014-2020, this contribution averaged 25\% of the total CAP budget in the EU and 20\% in the Czech Republic. The agroforestry sub-measure 8.2 in the Rural Development Regulation (Regulation 1305/2013) of the CAP 2014-2020 supported not only the establishment of agroforestry on agricultural land, but also the regeneration and management of existing areas of silvopasture. It was implemented in the Rural Development Plans of 35 (out of the 118) Regions in the EU. If fully implemented by the end of the CAP in 2020, around 74,000 ha of agroforestry should have been established or regenerated across the EU by the end of the programme in 2022 [33]. However, recent data (Szedlak pers. comm) on the implementation of this sub-measure shows that this target was greatly overestimated. By the end of 2019, its use had been established in Greece, leaving only Portugal, Spain, Italy, Belgium and the UK, and in five of the 34 Regional Development Plans. Only 2136 ha had been planted, at a cost of $3.3 \mathrm{M} €(2.5 \%$ of planned budget). Planned expenditure over the commitment period of the CAP 2014-2020 has been reduced to $64 \mathrm{M€}$.

Agencies responsible for administration of the CAP administration in the five states currently implementing sub-measure 8.2 have reported that farmers are reluctant to adopt the AF sub-measure because of the low payments offered, the limited time period of these payments and the risk that they will lose eligibility for Pillar I payments if their fields contain more than a threshold number of trees (the so called "100 trees/ha rule"). Member States often seem to realise that the EU never intended the threshold to apply to small trees but give no clarification on the crown diameter above which a tree will be "counted".

\subsubsection{Czech Implementation}

In the Czech Republic, AF is not yet recognized as a land use system in its LPIS or in its national cadastre. In Pillar One, 12 of the 19 possible EFAs listed in the Regulation 
1307/2013 were implemented, including six Landscape Features. However, less than $1 \%$ of the Ecological Focus Areas selected by farmers were Landscape Features, with Nfixing crops (61\%) and cover/catch crops (33\%) predominant (Table 4). The "Hectares of Agroforestry" EFA option was not implemented, as the Greening Delegated Regulation stipulates that this applies (a) only to silvoarable agroforestry and (b) only land planted using assistance from Rural Development Programmes-and such areas do not exist in the Czech Republic. The 100 tree/ha limit rule is applied to both arable land and permanent grassland to determine eligibility for basic payments, but the State Agricultural Intervention Fund, which administers agricultural subsidies, can further exclude the area under tree crown from the total area eligible for payment.

Table 4. Ecological Focused Areas implemented in the Czech Republic by 2016 as part of "greening" rules and cross-compliance measures [44,45].

\section{Ecological Focus Area Implemented in Czechia}

\section{Area Declared 2015 ha (\%)}

Notes (Including Whether Also

Recorded as a Good Agricultural and Environment Condition (GAEC) as Part of "Cross Compliance" in Pillar I)

\begin{tabular}{|c|c|c|c|}
\hline Hedges or woody strips & $\mathrm{n}$ & & \\
\hline Isolated Trees & $\mathrm{y}$ & & $\begin{array}{l}\text { Trees in isolation outside the forest with a } \\
\text { crown projection of at least } 8 \mathrm{~m}^{2} \text { (GAEC7) }\end{array}$ \\
\hline Trees in Line & $\mathrm{y}$ & & $\begin{array}{l}\text { Linear formation consisting of at least } \\
5 \text { trees (GAEC7) }\end{array}$ \\
\hline Trees in Groups/Copses & $\mathrm{y}$ & & $\begin{array}{c}\text { Separate non-linear formation with at } \\
\text { least } 2 \text { trees and largest area of } 3000 \mathrm{~m}^{2} \\
\text { (smaller than the forest definition) } \\
\text { (GAEC7) }\end{array}$ \\
\hline Field Margins & $\mathrm{y}$ & & GAEC5 (soil and carbon stock), GAEC7 \\
\hline Ponds/wetland & $\mathrm{y}$ & & $\begin{array}{l}\text { Ensure retention of water in a landscape, } \\
\text { cannot be damage, farming not permitted } \\
\text { (new in 2016), GAEC7 }\end{array}$ \\
\hline Ditches & $\mathrm{y}$ & & $\begin{array}{l}\text { Linear formation no more than } 6 \mathrm{~m} \text { width } \\
\text { whose function is to break slope length } \\
\text { (GAEC7) }\end{array}$ \\
\hline ATraditional stone walls & $\mathrm{n}$ & & \\
\hline $\begin{array}{l}\text { Other landscape features } \\
\quad \text { (grassed thalweg) }\end{array}$ & $\mathrm{y}$ & & $\begin{array}{l}\text { A path of water runoff from arable land, } \\
\text { reducing risk of erosion. Can be partially } \\
\text { covered with woody vegetation }\end{array}$ \\
\hline All landscape features & $\mathrm{y}$ & $261(0.09)$ & \\
\hline Fallow land & $\mathrm{y}$ & $16,179(5.4)$ & \\
\hline Terraces & $\mathrm{y}$ & & $\begin{array}{l}\text { Continuous linear formation serving to } \\
\text { reduce risk or water and wind erosion } \\
\text { and decreasing slope. Components can } \\
\text { be woody or a stone wall (GAEC7) }\end{array}$ \\
\hline Buffer/boundary strips & $\mathrm{n}$ & & \\
\hline $\begin{array}{l}\text { Hectares of agroforestry } \\
\text { (ha) }\end{array}$ & $\mathrm{n}$ & & \\
\hline $\begin{array}{l}\text { Forest edge strips-non } \\
\text { productive }\end{array}$ & $\mathrm{n}$ & & \\
\hline $\begin{array}{l}\text { Forest edge } \\
\text { strips-productive }\end{array}$ & $\mathrm{n}$ & & \\
\hline Short rotation coppice & $\mathrm{y}$ & $83(0.03)$ & \\
\hline Afforested areas & $\mathrm{y}$ & $188(0.06)$ & \\
\hline Cover or catch crops & $\mathrm{y}$ & $99,909(33.2)$ & $\begin{array}{l}\text { Also recorded for GAEC4 (minimum soil } \\
\text { cover) }\end{array}$ \\
\hline N-fixing crops & $\mathrm{y}$ & $182,326(60.7)$ & $\begin{array}{l}\text { Also recorded for GAEC6 (maintenance } \\
\text { of soil organic matter level through } \\
\text { appropriate practices) }\end{array}$ \\
\hline
\end{tabular}


While the Czech Republic did not support the AF sub-measure 8.2 of the Reg. (EU) $1305 / 2013$, it did support extensive grazed orchards with landscape and ecological value within Rural Development Programme of CAP 2014-2020. Short rotation coppice is also eligible for direct payments, and counts towards the greening threshold, but not in combination with crops or livestock production. Only small animal breeding or grazing are accepted (chicken, hens, sheep, etc.) and schemes must comply with the rules for short rotation coppice trees (planting density, rotation, manipulation space).

\section{Discussion}

\subsection{Traditional Agroforestry Practices and Their Conservation}

Our results confirm that AF used to be relatively common land use in the Czech Republic but was largely eliminated from the landscape due to the agricultural intensification or abandonment of less productive areas, accelerated mainly during the era of collectivization after WWII. This intensification has marginalized traditional AF practices to areas with environmental constraints for intensive agriculture, where the only remnants can be found (Figure 5). Most of them were converted to tree-less pastures or were reforested. In fertile lowland, with predominance of arable farming, AF completely disappeared. Traditional AF systems are currently extended on less than $1 \%$ of agricultural land in the Czech Republic, all of them classified as silvopastoral AF (wood pastures or orchard grazing). These values are much lower than the majority of countries in the Central and Eastern Europe like Germany (1.6\%), Austria (5.6\%), Slovakia (2.3\%), Romania (6.7\%) or Bulgaria (19.4\%), but comparable to Poland (0.7\%) and Hungary (0.8\%) [30]. Despite their low extent, these areas are of high natural and cultural value, because the vegetation complexity and (species) diversity provides a wide range of ecosystem and cultural services [13].

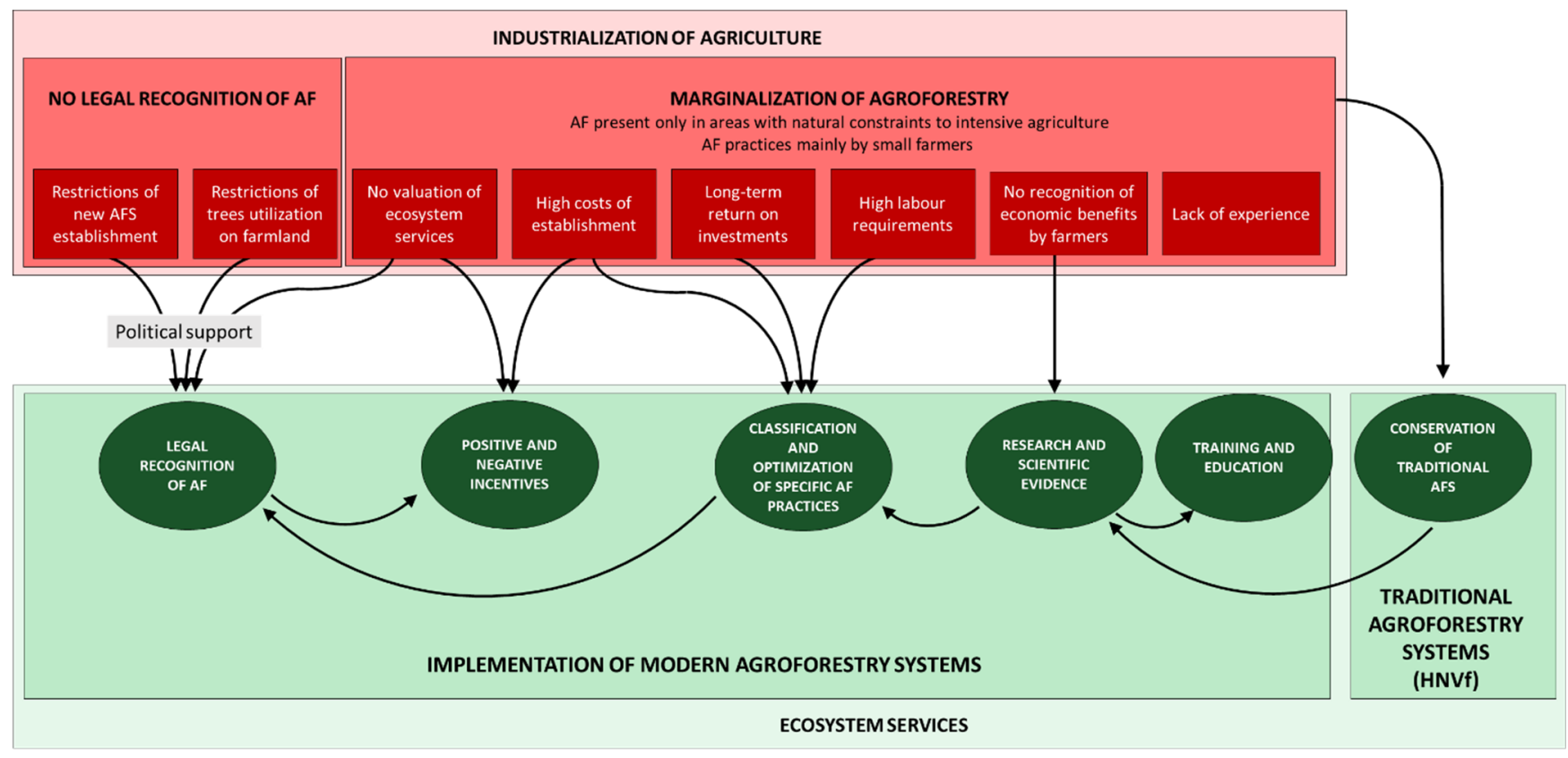

Figure 5. Diagram of the main barriers (red squares) and recommendations (green circles) for the development of agroforestry in the Czech Republic.

While the primary product of such AF practices is livestock, there is a range of other traditional marketed products in other European countries: some are no longer of high (economic) importance due to high labour costs (tree hay, firewood, charcoal, and fruits), while others found a niche on the market and are often specifically labelled (e.g., Iberian ham). Some of these AF are primarily designed (or preserved) as aesthetic landscape of high cultural value with high potential for tourism and recreation [13]. The traditional 
grazed orchards in the Czech Republic are based on the cultivation of local high-stemmed fruit tree varieties and thus possess high value for in-situ conservation of this traditional germplasm. There are various initiatives, e.g., in Bílé Karpaty region (Moravia), aiming to conserve and reproduce such traditional varieties and market their products, which include fruit juices, cider, dried fruits and plum brandy. This region also profits from agrotourism because of its beautiful cultural landscape based on traditional AF.

Nevertheless, the sustainability of such AF could be supported by placing a monetary value on public cultural benefits by local and national governments [14]. The standard conservation approach in Europe is characterized by payments to farmers for maintaining traditional farming practices, e.g., through agri-environmental schemes. However, attempting to conserve past land-use systems through financial incentives cannot restore the intricate cultural linkages between people and their landscape [46]. "The transformation strategy" may include developing markets for organic or regional specialty products, ecotourism, and localized production of biomass energy [47]. Despite the indisputable cultural and ecological importance of the remnant traditional AF, the development of contemporary and innovative farming (such as novel silvoarable AF, or localized production) should be advised $[48,49]$ to avoid farmers being dependent only on subsidies.

Our estimation of current AF extent in the Czech Republic based on LUCAS is lower than reported previously [30] (35,750 ha compared to 45,800 ha), which can be explained by a more detailed check of all individual points classified as AF by LUCAS as performed in our study. This could also occur in other countries. On the other hand, a low sampling density used by LUCAS also likely underestimates the extension of grazed orchards (our estimation was $5720 \mathrm{ha}$ ), as such AF is usually practiced on rather small plots, often not detected by this method. It has been recently estimated [50] that the extension of the traditional grazed orchards or orchard meadows in the Czech Republic could be between 10 and 55 thousand hectares, depending on the used methodology and definition. As such, all the estimations of the extent of AF depend on the methodology used and the nature of the wide variety of AF systems makes those estimations difficult.

Using LUCAS, there is also no clear recognition of field boundary AF (windbreaks, shelterbelts, wooded hedges, and riparian tree strips). The use of hedges and live fences along the field borders, streams and slope contours has a long tradition, but the era of joining fields to larger blocks led to their drastic reduction and their current extent is challenging to estimate. The recognition of such systems for biodiversity conservation (so called green infrastructure) has been steadily increasing and their establishment is promoted. Nevertheless, they are usually not included in agricultural land or are classified as Landscape Features in LPIS. However, the extent of Landscape Features in the national inventory (LPIS) is still negligible, as their registration is voluntary and farmers are reluctant to do so, because different rules and requirements apply to such areas. If registered, they must be protected, and their management or removal is restricted. Such areas generally lack productive function and should be protected for their ecological functions. Another type of AF not covered by any of the national inventories are traditional homegardens on nonagricultural land, which, although very popular and of high cultural importance, are usually too small and inconsistent. Hence, the quantification of their extension is problematic.

\subsection{Current State of Agroforestry and Barriers for Implementation}

To the best of our knowledge, no modern large-scale silvoarable (tree/coppice alley cropping) AF is currently present in the Czech Republic. While Czech farmers showed relatively high interest in establishing AF in our quantitative survey, they also expressed a great uncertainty towards AF, concerning mainly: (i) bureaucratization of the establishment under current legislation; (ii) lack of evidence of the economic benefits-linked to high labour requirements and additional investments in tree establishment, protection and new farming technologies, and with compromised productivity; and (iii) lack of experience, methodological support and training (Figure 5). While the majority of the farmers participating in the farmers' survey were interested in the establishment of AF, it should be noted 
that this value may be overestimated, since interested farmers were probably more likely to return the questionnaire.

The bureaucratization connected with growing woody perennials on the agricultural land is the biggest concern to farmers. Such findings are not surprising, given that there is no recognition of AF in the current Czech legislation (Figure 5), which poses a high number of obstacles to the tree establishment on agricultural land (except in orchards). Barriers relate particularly to the EU Delegate Regulation (which will not be renewed in the next CAP 2023-27), which limits the number of cultivated trees on agricultural land to 100 trees per hectare, and by the Czech Agricultural Act and following directives and regulations, which state that only one crop group can be established on a part of a farmer's block (registered in LPIS). This practically excludes the combination of crop or grassland with a tree component and also disqualifies the trees (except fruit trees) from being recognized as a productive component. Moreover, the woody vegetation growing outside the forest (trees already present on the agricultural land) is protected according to the Nature and Landscape Protection Act, hence cannot be managed and harvested without specific permission. Concerning agricultural subsidies, the area covered by woody vegetation on fields can be classed as "ineligible" for basic payments or classed as a Landscape Feature in LPIS. In the former case, the annual direct Pillar I payments would be reduced based on the reduced total area of agricultural land, and in the later, such woody areas can no longer be used, managed, or harvested freely by the farmer. Thus, AF has to be politically and legally recognized (with clear definition and classification, as presented in Tables 1 and 2) in various directives and regulations and accepted as specific crop group(s) in LPIS to open the possibility for farmers to plant, manage, and harvest trees on agricultural land.

Despite the bureaucratic obstacles, most of the Czech farmers still have some experience with trees or woody vegetation on their farmland and their prime motivation to maintain and establish them is the aesthetical function of trees in the landscape, clearly confirming the findings from other European countries [16] where landscape aesthetics also gained the highest score. Hence, farmers with a larger number of trees on their (particularly privately owned, not leased) farmland, are more open to the AF establishment. The majority of farmers acknowledged the positive effect of trees on animal welfare by providing shade and shelter, hence silvopastoral AF seems to be more popular and more easily accepted by farmers. Most of the farmers also highly value the ecosystem services provided by the trees, particularly erosion control, microclimate improvement, and biodiversity conservation. On the other hand, for farmers whose only income is annual crop production, the trees within the arable land directly translate into the loss of income, without considering changes in productivity or reduced requirements for inputs. Usually based on their personal experience, farmers are concerned about the tree-crop competition for water and light, while they generally do not believe that trees are able to improve crop production through the improvement in soil fertility. This divergency between ecological and economic view of AF among Czech farmers greatly differs from other countries, where income diversification and possible increase of productivity has been seen as major benefit of trees on agricultural land $[16,51,52]$ and is likely a result of a long period of intensive agriculture and loss of experience with AF. The low expectation of the productive role of trees could be explained by the generally accepted long-term and low profitability of the current wood production and by the excessively high labour requirements of fruit production. High complexity of management and increased workload under a current shortage of agricultural labour could be serious obstacles to AF adoption. In line with other authors [53,54], subsidies would be unlikely to greatly change the average farmers' views; however, they could help the interested farmers to finance the establishment of AF.

Based on our results, the farmers who are more willing to establish AF tend to have: (i) organic farms, (ii) relatively small holdings, (iii) low shares of arable land (mixed cropanimal farming), (iv) predominantly privately owned land, and (v) at least some trees on their farmland. All these characteristics represent a typical European family farm. 
Nevertheless, higher inclination of farmers to establish AF on their own land, when over $70 \%$ of agricultural land is leased in the Czech Republic, together with the strong intensification of agriculture and concentration of managed farmland under large companies, indicate serious obstacles for large-scale adoption of AF in the Czech Republic. A similar situation can be expected in other countries with the same historical background (Central and Eastern European countries, including Eastern Germany and Slovakia). However, in countries, where the collectivization of agriculture did not have such a strong impact and most farmland is still managed predominantly as family farms (e.g., Poland, Austria, Hungary, Bulgaria, and Romania) [2], higher openness of farmers to implement AF can be expected, if sufficiently promoted and supported.

The current low extent of AF in the Czech Republic found in our study in comparison with other European countries [30] can be explained by (i) historically different ways of agricultural intensification (especially after WWII); (ii) loss of experience with AF during decades of intensive agriculture and thus low re-adoption of these traditional farming practices (usually practiced on smaller family farms); and (iii) number of legislative, bureaucratic and economic barriers for planting trees on agricultural land (Figure 5). To address these issues, agroforestry courses are currently implemented in several study programs at the two agricultural universities-Czech University of Life Sciences Prague (CZU) and Mendel University in Brno. Furthermore, the Czech Association for Agroforestry (CSAL), a member of the European Agroforestry Federation (EURAF), has organized a number of AF trainings, workshops, and conferences for farmers and landowners. A recent European-scale project AGFOSY, also implemented in the Czech Republic, has been financed through the ERASMUS+ program to develop training materials including case studies, methodological lists of best practices, short videos and other study materials to increase the overall knowledge of AF. The output of the project was a simple online module for agroforestry training (www.agroforestrysystems.eu) (accessed on 07 August 2020). The first larger national agroforestry research project, with the title "Agroforestry-potential for regional development and sustainable rural landscape" was executed in 2018-20. One of the outcomes of the project was publication of an AF handbook, guiding the establishment and management of AF directly targeted for use by farmers. The Ministry of the Environment initiated another research project in 2019 titled "Agroforestry systems for protection and restoration of landscape functions endangered by climate change and human activity", focusing on evaluation of trade-offs between agricultural production and ecosystem services in AF.

Clearly, the discrepancy between (i) the increasing promotion of AF at a scientific level based on the empirical evidence of AF economic benefits and environmental services (much lower in the Czech Republic in comparison with the rest of Europe), and (ii) the relatively slow elimination of legislative obstacles to AF establishment (both on an EU and national level), need to be addressed for a successful AF re-introduction into Czech and European landscapes. The next step should be the development of a training and advisory service for farmers interested in AF establishment. The AF training should be incorporated in the European Agricultural Knowledge and Innovation Systems (AKIS) and into the established national agriculture advisory service and its existing infrastructure (e.g., training of the accredited advisors, information service etc.). Such support should be also created at the farmers' organizations level. In the Czech Republic, the Association of Private Farming currently plays an active role in developing AF and is beginning to prepare, together with CSAL, the agroforestry advisory service for their members.

\subsection{Future Perspectives of Agroforestry under the New CAP}

Plans for the CAP 2023-2027 were first published in June 2018 in the draft Strategic Plan Regulation (Proposal for a Regulation establishing rules on support for national strategic plans to be drawn up by Member States under the CAP Strategic Plans). This reform is intended to move the CAP from compliance towards results and performance and includes a new distribution of responsibilities between the Commission and the Member 
States. The proposal provides more subsidiarity and flexibility and should bring new opportunities for the member states to design measures that better support local needs and priorities with simpler administrative procedures.

The draft Regulation mentions "agroforestry" several times, e.g., in connection with the framework definition for "arable land", which: "should allow member states to cover different production forms, including systems such as agroforestry and arable areas with shrubs and trees". Agroforestry in CAP 2023-2027 will be eligible for 5-year Rural Development "forestry" investment support (equivalent to Article 23 in the CAP 2014-2020), as well as (potentially) for annual payments under the terms of equivalent of the current Article 23, which is paid to Agri-Environment-Climate Measures (Pillar II). Agroforestry could also be funded from nationally funded agricultural schemes that follow the rules for "state-aid to agriculture", such as the present Support and Guarantee Peasant and Forestry Fund$\mathrm{SCPFF}$ ), and potentially also for annual payments as part of the Agri-Climate-Environment Measure (Article 28). There are specific mentions of agroforestry in the European "Green Deal", "Farm to Fork" and "Biodiversity Strategy". Agroforestry is currently one of the most important strategies to fulfil the three billion trees planting pledge by 2030 (European Commission 2021, The 3 billion Tree Planting Pledge for 2030). Clearly, both European and Czech agricultural policies are changing in favour of environmentally friendly agricultural production, sustainability, rural development, climate change amelioration strategies and biodiversity enhancement, with AF being one of the key strategies to fulfil these goals.

Agroforestry has been included in the National CAP Strategic Plan 2023-2027 and The Czech Ministry of Agriculture, together with the Ministry of Environment, are therefore proposing a new AF measure (one of the Agri-Climate-Environment Measures) to support establishment and maintenance of AF, similar to the previous Article 23/Measure 8.2 support. This is being prepared for the new Czech Rural Development Plan, and established AF parcels will be registered by farmers in the Czech Land Parcel Identification System (LPIS) - as crop type subcategories on arable land or permanent grassland. Two categories are proposed for support: (i) silvoarable AF (80-100 of forest or fruit trees per ha grown in alley cropping design on arable land); and (ii) and silvopastoral AF (80-100 scattered trees per ha on permanent grasslands). Financial support will be provided for the establishment, and maintenance during the first five years. A list of permitted tree species for AF has been prepared and it is divided into primary tree species, for which subsidies will be given, and supplementary tree species and shrubs, which will not be subsidized. The measure will include a condition that one tree species must not account for more than $40 \%$ of all tree species (i.e., at least three species must be planted) and at least $50 \%$ of trees must be forest trees. We believe, the implementation of this measure will be linked to the partial elimination of legislative barriers in various directives and regulations and will lead to substantial simplification of the administrative burden connected with tree planting on agricultural land.

\subsection{Recommendations for Further Agroforestry Development}

From the obtained results, family farms in particular are more prone and willing to establish $\mathrm{AF}$, hence the agriculture extension service should first focus on them to promote and implement AF. The outputs of various projects mentioned above should create enough educational and training materials for such a purpose. In the Czech Republic, the Association of Private Farming, which represents family farmers, could form a suitable bridge between research and development and farmers themselves. However, most agricultural land in Europe and particularly in the Czech Republic is currently managed by large-scale enterprises, with the main focus on intensive, industrial farming, targeting mainly economical outputs. The economic efficiency of these companies is largely dependent on current European agricultural subsidies. Thus, they have to be guided by positive (e.g., subsidies for AF establishment) and negative (regulation and directives that leads to environmentally friendly management) incentives (Figure 5). The substantial change in favour of AF could only occur if those big players get involved, which means a clear political support for AF. 
The proposal of the new CAP 2023-2027 could be a good guiding tool, which then needs to be applied by political representation. As mentioned above, many AF practices fit into the broader definition of high nature value farming [13] that is currently highly appreciated by the general public and should also be a target for support from political representation.

Under the new CAP 2023-2027, and in line with EU Farm to Fork and Biodiversity Strategies, there is a strong potential for development of AF. The financial support for establishment and management of AF must be clear and simple, without legislative obstacles and bureaucratic burdens, which may impede AF adoption.

For future development of AF, we recommend (Figure 5):

(i) Maintenance of traditional AF, for their high nature and cultural values, could be supported under already existing schemes. However, innovative and novel ways of support, such as regional specialty products, ecotourism or inclusion of energy crops, need to be developed.

(ii) The proposed classification of AF should be included in the legislation and for future inventory we recommend the creation of a specific (sub)category for AF practices in the existing pan-European LPIS.

(iii) Agroforestry should be included in the National CAP Strategic Plans (in Czech Republic as well as other countries). Those AF practices that will be financially supported should be promoted and connected with the established advisory service (such as AKIS). What is needed are detailed rules covering establishment and maintenance and confirming the conditions for eligibility. If designed well, such support can probably attract even large agricultural companies to start agroforestry.

(iv) Target regions for support of re-implementation should be intensively managed arable farmlands, where modern silvoarable practices (tree/coppice alley cropping), adapted to intensive farming, could bring a number of ecosystem services.

(v) Although research, development, and training in AF has already started, it needs to be further accelerated to generate results that farmers can use and implement into their practice by an established advisory service.

(vi) AF needs clear political support to be included in various strategies, regulations, and support measures, to create positive as well as negative incentives for farmers to plant and manage trees on their farmland.

\section{Conclusions}

Our study confirmed that AF was once a common land use in the Czech Republic, which was marginalized by industrial agriculture. Because AF is not a valid land use system in the Czech legislative, such areas are considered as standard permanent grasslands (if the number of trees does not exceed 100 per ha) and orchards, or as Landscape Features and non-productive land. No modern AF (particularly alley cropping allowing mechanization and large-scale implementation) was detected in the present study by LUCAS. We also observed that farmers are relatively open to AF adoption, but AF is perceived as something new and unknown, rather than a traditional land-use system. Farmers are mainly concerned by the bureaucratic barriers, currently blocking the AF establishment, but also by insufficient knowledge to establish and maintain productive and economically viable AF. Thus, the re-implementation of AF is hindered by current legislation and by the results of AF marginalization during the agricultural industrialization, mainly the loss of experience. Such barriers could be eliminated by political and legislative recognition and support (financial incentives, research and dissemination, training, and advisory service). Nevertheless, the majority of farmers (particularly organic farmers with farms up to $50 \mathrm{ha}$ ) are willing to establish AF on their (particularly privately owned) land, mainly due to the environmental benefits of trees. While the situation in the Czech Republic is partially representative for other European countries, based on the unique combination of (i) the historical evolution of Czech agriculture (resulting in lower proportion of small farms and higher proportion of leased agricultural area in comparison to European average) and (ii) the strict current Czech legislation excluding AF from agricultural land use systems, 
the farmers' willingness to adopt (or re-adopt) AF in the rest of Europe can be expected to be higher. Based on the synthesis of the historical background and the current situation in the Czech Republic including farmers' perception and AF-related legislatives, we conclude that AF practices need to be legally recognized and supported by research and dissemination. Only then can agroforestry be accepted by farmers and optimized to fit the environmental, socio-economic, and legislative conditions to form a part of the mainstream European agriculture.

Author Contributions: Conceptualization, B.L., N.T., A.C. and G.L.; historical survey, P.S., J.K. and T.Z.; classification and extension of AF, B.L., A.M., J.H., J.Č., R.K. and J.W.; farmer' perception survey L.K. and M.S.; Legal aspects, H.D., J.J., K.V., T.K. and G.L.; writing-review and editing, B.L., N.T., A.C. and G.L.; funding acquisition, B.L. All authors have read and agreed to the published version of the manuscript.

Funding: This research was supported by the Technological Agency of the Czech Republic (grant No. TL01000298) and Internal Grant Agency of CZU Prague (grant No. 20213110). This study was also supported as a long-term research development project no. RVO 67985939.

Institutional Review Board Statement: Not applicable.

Informed Consent Statement: Not applicable.

Data Availability Statement: The data that support the findings of this study are openly available in Open Science Framework at https: / / osf.io/p4tf3 /?view_only=a47280b251694b0a9f9e6964155e0cfc (accessed on 10 November 2020).

Acknowledgments: We are grateful to all farmers participating in our focus group discussions and farmer survey.

Conflicts of Interest: The authors declare no conflict of interest.

\section{References}

1. Čermáková, K.; Mácová, M. Integrované Šetření v Zemědělství-2020; Český Statistický Úřad: Ceske Budejovice, Czech Republic, 2021. Available online: https:/ / www.czso.cz/csu/czso/integrovane-setreni-v-zemedelstvi-2020 (accessed on 9 July 2020 ).

2. Eurostat. Farms and Farmland in the European Union-Statistics. 2016. Available online: https://ec.europa.eu/eurostat/statisticsexplained/index.php?title=Farms_and_farmland_in_the_European_Union_-_statistics\#Farms_in_2016 (accessed on 9 July 2020).

3. Ministry of Agriculture. Situační a Výhledová Zpráva Půda; Ministry of Agriculture: Prague, Czech Republic, 2018.

4. Bičík, I.; Kupková, L.; Jeleček, L.; Kabrda, J.; Štych, P.; Janoušek, Z.; Winklerová, J. Land Use Changes in the Czech Republic 1845-201: Socio-Economic Driving Forces; Springer International Publishing: Berlin, Germany, 2015; ISBN 978-3-319-17670-3.

5. Lipsky, Z. Historical development of the Czech rural landscape used to its present ecological stabilization. Ekologia 1996, 15, 105-109.

6. Lipsky, Z. The changing face of the Czech rural landscape. Landsc. Urban Plan. 1995, 31, 39-45. [CrossRef]

7. Bičík, I.; Jeleček, L.; Kabrda, J.; Kupková, L.; Lipský, Z.; Mareš, P.; Šefrna, L.; Štych, P.; Winklerová, J. Vývoj Využití Ploch v Česku, 1st ed.; Česká Geografická Společnost: Prague, Czech Republic, 2010; ISBN 978-80-905421-3-8.

8. Ontl, T.A.; Cambardella, C.A.; Schulte, L.A.; Kolka, R.K. Factors influencing soil aggregation and particulate organic matter responses to bioenergy crops across a topographic gradient. Geoderma 2015, 255, 1-11. [CrossRef]

9. Reif, J.; Vermouzek, Z. Collapse of farmland bird populations in an Eastern European country following its EU accession. Conserv. Lett. 2019, 12, e12585. [CrossRef]

10. Sutcliffe, L.M.E.; Batáry, P.; Kormann, U.; Báldi, A.; Dicks, L.V.; Herzon, I.; Kleijn, D.; Tryjanowski, P.; Apostolova, I.; Arlettaz, R.; et al. Harnessing the biodiversity value of Central and Eastern European farmland. Divers. Distrib. 2015, 21, 722-730. [CrossRef]

11. Smith, J.; Pearce, B.D.; Wolfe, M.S. Reconciling productivity with protection of the environment: Is temperate agroforestry the answer? Renew. Agric. Food Syst. 2013, 28, 80-92. [CrossRef]

12. Udawatta, R.P.; Rankoth, L.M.; Jose, S. Agroforestry and biodiversity. Sustainability 2019, 11, 2879. [CrossRef]

13. Moreno, G.; Aviron, S.; Berg, S.; Crous-Duran, J.; Franca, A.; de Jalón, S.G.; Hartel, T.; Mirck, J.; Pantera, A.; Palma, J.H.N.; et al. Agroforestry systems of high nature and cultural value in Europe: Provision of commercial goods and other ecosystem services. Agrofor. Syst. 2018, 92, 877-891. [CrossRef]

14. Rolo, V.; Hartel, T.; Aviron, S.; Berg, S.; Crous-Duran, J.; Franca, A.; Mirck, J.; Palma, J.H.N.; Pantera, A.; Paulo, J.A.; et al. Challenges and innovations for improving the sustainability of European agroforestry systems of high nature and cultural value: Stakeholder perspectives. Sustain. Sci. 2020, 15, 1301-1315. [CrossRef] 
15. Den Herder, M.; Burges, P.; Mosquera-Losada, M.; Herzog, F.; Hartel, T.; Upson, N.; Viholainen, L.; Rosati, A. Preliminary Stratification and Quantification of Agroforestry in Europe; Milestone Report 1.1 for EU FP7 AGFORWARD Research Project (613520); European Commission: Brussels, Belgium, 2015.

16. García de Jalón, S.; Burgess, P.J.; Graves, A.; Moreno, G.; McAdam, J.; Pottier, E.; Novak, S.; Bondesan, V.; Mosquera-Losada, R.; Crous-Durán, J.; et al. How is agroforestry perceived in Europe? An assessment of positive and negative aspects by stakeholders. Agrofor. Syst. 2018, 92, 829-848. [CrossRef]

17. Kirby, K.J.; Watkins, C. Europe's Changing Woods and Forests: From Wildwood to Managed Landscapes; CABI: Wallingford, UK, 2015; ISBN 9781780643373.

18. Plieninger, T.; Hartel, T.; Martín-López, B.; Beaufoy, G.; Bergmeier, E.; Kirby, K.; Montero, M.J.; Moreno, G.; Oteros-Rozas, E.; Van Uytvanck, J. Wood-pastures of Europe: Geographic coverage, social-ecological values, conservation management, and policy implications. Biol. Conserv. 2015, 190, 70-79. [CrossRef]

19. Hartel, T.; Nita, A.; Rozylowicz, L. Understanding human-nature connections through value networks: The case of ancient wood-pastures of Central Romania. Sustain. Sci. 2020, 155, 1357-1367. [CrossRef]

20. Torralba, M.; Fagerholm, N.; Hartel, T.; Moreno, G.; Plieninger, T. A social-ecological analysis of ecosystem services supply and trade-offs in European wood-pastures. Sci. Adv. 2018, 4, eaar2176. [CrossRef]

21. Nair, P. State-of-the-art of agroforestry research and education. In Agroforestry Systems. Presented at the International Conference on Directions in Agroforestry: A Quick Appraisal; Kluwer Academic Publishers: Dordrecht, The Netherlands, 1993.

22. Eichhorn, M.P.; Paris, P.; Herzog, F.; Incoll, L.D.; Liagre, F.; Mantzanas, K.; Mayus, M.; Moreno, G.; Papanastasis, V.P.; Pilbeam, D.J.; et al. Silvoarable Systems in Europe-Past, Present and Future Prospects. Agrofor. Syst. 2006, 67, 29-50. [CrossRef]

23. Atangana, A.; Khasa, D.; Chang, S.; Degrande, A. Definitions and Classification of Agroforestry Systems. In Tropical Agroforestry; Atangana, A., Khasa, D., Chang, S., Degrande, A., Eds.; Springer: Dordrecht, The Netherlands, 2014; pp. 35-47, ISBN 9789400777231.

24. Lundgren, B.; Raintree, J.B. Agroforestry. In Proceedings of the Conference of Directors of National Agro-Forestry Research Systems in Asia, Jakarta, Indonesia, 24-29 October 1982; p. 12.

25. European Commission. Regulation (EU) no 1305/2013 of the European Parliament and of the Council of 17 December 2013 on Support for Rural Development by the European Agricultural Fund for Rural Development (EAFRD) and Repealing Council Regulation (EC) No 1698/2005; European Commission: Brussels, Belgium, 2013.

26. Dupraz, C.; Lawson, G.J.; Lamersdorf, N.; Papanastasis, V.P.; Rosati, A.; Ruiz-Mirazo, J. Temperate agroforestry: The European way. In Temperate Agroforestry Systems, 2nd ed.; CABI: Wallingford, UK, 2018.

27. Krčmářová, J. Forgetting Traditional Agricultural Knowledge in Modernization. Interdisciplinry Historical Reconstruction of Czech Agroforestry; Charles University: Prague, Czech Republic, 2015.

28. Krčmářová, J.; Jeleček, L. Czech traditional agroforestry: Historic accounts and current status. Agrofor. Syst. 2017, 91, 1087-1100. [CrossRef]

29. Szabó, P.; Suchánková, S.; Kř́žžová, L.; Kotačka, M.; Kvardová, M.; Macek, M.; Müllerová, J.; Brázdil, R. More than trees: The challenges of creating a geodatabase to capture the complexity of forest history. Hist. Methods A J. Quant. Interdiscip. Hist. 2018, 51, 175-189. [CrossRef]

30. den Herder, M.; Moreno, G.; Mosquera-Losada, R.M.; Palma, J.H.N.; Sidiropoulou, A.; Santiago Freijanes, J.J.; Crous-Duran, J.; Paulo, J.A.; Tomé, M.; Pantera, A.; et al. Current extent and stratification of agroforestry in the European Union. Agric. Ecosyst. Environ. 2017, 241, 121-132. [CrossRef]

31. Burgess, P.; Crous-Duran, J.; den Herder, M.; Dupraz, C.; Fagerholm, N.; Freese, D.; Garnett, K.; Graves, A.; Hermansen, J.; Liagre, F.; et al. AGFORWARD Project Periodic Report: January to December 2014; European Commission: Brussels, Belgium, 2015.

32. Krčmářová, J.; Kala, L.; Brendzová, A.; Chabada, T. Building Agroforestry Policy Bottom-Up: Knowledge of Czech Farmers on Trees in Farmland. Land 2021, 10, 278. [CrossRef]

33. Lawson, G.; Belaguer, F.; Palma, J.H.N.; Papanastasis, V. Options for Agroforestry in the CAP 2014-2020. 2016. Available online: https:/ / docs.google.com/document/d/1koFQwxUvPMiIN4gF9YABq0CT4BiAV8mkYz8gNpWkY4I/edit\#heading=h. 8esol67mz0o3 (accessed on 15 August 2020).

34. Pokorný, P.; Chytrý, M.; Juřičková, L.; Sádlo, J.; Novák, J.; Ložek, V. Mid-Holocene bottleneck for central European dry grasslands: Did steppe survive the forest optimum in northern Bohemia, Czech Republic? Holocene 2015, 25, 716-726. [CrossRef]

35. Kuneš, P.; Svobodová-Svitavská, H.; Kolář, J.; Hajnalová, M.; Abraham, V.; Macek, M.; Tkáč, P.; Szabó, P. The origin of grasslands in the temperate forest zone of east-central Europe: Long-term legacy of climate and human impact. Quat. Sci. Rev. 2015, 116, 15-27. [CrossRef]

36. Beranová, M. Zemědělství Starých Slovanů; Academia: Prague, Czech Republic, 1980.

37. Beranová, M.; Kubačák, A. Dějiny zemědělství v Čechách a na Moravě; Libri: Prague, Czech Republic, 2010.

38. Konečný, L. Románská Rotunda ve Znojmě: Ikonologie Maleb a Architektury; Host: Prague, Czech Republic, 2005 ; ISBN 8072941712.

39. Szabó, P. Rethinking pannage: Historical interactions between oak and swine. In Trees, Forested Landscapes and Grazing Animals: A European Perspective on Woodlands and Grazed Treescapes; Rotherham, I., Ed.; Routledge: Abingdon, UK, 2013 ; pp. 51-61.

40. Liebich, C. Der Waldbau Nach Neuen Grundsätzen als die Mutter des Ackerbaues; J. G. Calve'sche Buchhandlug: Prague, Czech Republic, 1834. 
41. Svobodová, K. Zemědělství na Jižní a Jihovýchodní Moravě v Polovině 19. Století ve Světle Stabilního Katastru; Národní zemědělské muzeum: Prague, Czech Republic, 2014; ISBN 9788086874487.

42. Szabó, P. Traditional woodland management, forest legislation and modern nature conservation in East-Central Europe. In Conservation's Roots: Managing for Sustainability in Preindustrial Europe, 1100-1800; Dowling, A.P., Keyser, R., Eds.; Berghahn: New York, NY, USA, 2020; pp. 304-326, ISBN 9781789206920.

43. EFI; CTFC; IEEP. Ex-post Evaluation of the EU Forest Action Plan; European Union: Brussels, Belgium, 2012.

44. European Commission. Commission Staff Working Document-Reviwing of Greening after One Year. 2016. Available online: https:/ / ec.europa.eu/transparency/documents-register/detail?ref=SWD(2016)218\&lang=EN (accessed on 28 August 2020).

45. Osoha, B. GAEC and EFA Common Features Implemented in Czech Republic; GAEC Greening Workshop: Prague, Czech Republic, 2015. Available online: https:/ / ec.europa.eu/jrc/sites/default/files/osoha.pdf (accessed on 28 August 2020).

46. Daniel, T.C.; Muhar, A.; Arnberger, A.; Aznar, O.; Boyd, J.W.; Chan, K.M.A.; Costanza, R.; Elmqvist, T.; Flint, C.G.; Gobster, P.H.; et al. Contributions of cultural services to the ecosystem services agenda. Proc. Natl. Acad. Sci. USA 2012, 109, 8812-8819. [CrossRef]

47. Plieninger, T.; Bieling, C. Resilience-based perspectives to guiding high-nature-value farmland through socioeconomic change. Ecol. Soc. 2013, 18, 20. [CrossRef]

48. Plieninger, T.; Bieling, C.; Ohnesorge, B.; Schaich, H.; Schleyer, C.; Wolff, F. Exploring futures of ecosystem services in cultural landscapes through participatory scenario development in the Swabian Alb, Germany. Ecol. Soc. 2013, 18, 39. [CrossRef]

49. Strohbach, M.W.; Kohler, M.L.; Dauber, J.; Klimek, S. High Nature Value farming: From indication to conservation. Ecol. Indic. 2015, 57, 557-563. [CrossRef]

50. Forejt, M.; Syrbe, R.U. The current status of orchard meadows in Central Europe: Multi-source area estimation in Saxony (Germany) and the Czech Republic. Morav. Geogr. Rep. 2020, 27, 217-228. [CrossRef]

51. Graves, A.; Burgess, P.; Liagre, F.; Dupraz, C. Farmer perception of benefits, constraints and opportunities for silvoarable systems. Outlook Agric. 2017, 46, 74-83. [CrossRef]

52. Graves, A.R.; Burgess, P.J.; Liagre, F.; Pisanelli, A.; Paris, P.; Moreno, G.; Bellido, M.; Mayus, M.; Postma, M.; Schindler, B.; et al. Farmer perceptions of silvoarable systems in seven European Countries. In Agroforestry in Europe; Rigueiro-Rodríguez, A., McAdam, J., Mosquera-Losada, M., Eds.; Springer: Dordrecht, The Netherlands, 2009; pp. 67-86.

53. Sereke, F.; Dobricki, M.; Wilkes, J.; Kaeser, A.; Graves, A.R.; Szerencsits, E.; Herzog, F. Swiss farmers don't adopt agroforestry because they fear for their reputation. Agrofor. Syst. 2016, 90, 385-394. [CrossRef]

54. Louah, L.; Visser, M.; Blaimont, A.; de Cannière, C. Barriers to the development of temperate agroforestry as an example of agroecological innovation: Mainly a matter of cognitive lock-in? Land Use Policy 2017, 67, 86-97. [CrossRef] 